American Journal of Applied Sciences 7 (6): 746-755, 2010

ISSN 1546-9239

(C) 2010Science Publications

\title{
Upgrading of Bio-Oil into High-Value Hydrocarbons via Hydrodeoxygenation
}

\author{
Murni M. Ahmad, M. Fitrir R. Nordin and M. Tazli Azizan \\ Department of Chemical Engineering, University Technology PETRONAS, \\ 31750 Perak, Malaysia
}

\begin{abstract}
Problem statement: World energy consumption is forecasted to grow significantly for the foreseeable future with fossil fuel remains the governing energy source. The demand in the need to explore alternative fuel source was further triggered by the overwhelmingly inconsistent cost of gasoline. Bio-oil is an alternative energy source produced from pyrolysis of biomass. However it is undesirable as a ready alternative transportation fuel due to its unfavorable nature i.e., highly oxygenated and low octane number. To overcome these physicochemical issues, hydrodeoxygenation reaction is a possible upgrading method i.e., by partial or total elimination of oxygen and hydrogenation of chemical structures. Hence, this study aimed to investigate feasible routes and to develop the process route to upgrade the pyrolytic bio-oil from biomass into value-added chemicals for the production of transportation fuel, i.e., benzene and cyclohexane, via hydrodeoxygenation process via simulation in PETRONAS iCON software. Approach: In this study, hydrodeoxygenation of phenols and substituted phenols was used to represent the hydrodeoxygenation of the major oxygen compound in bio-oil due to their low reactivity in HDO. Results: By assuming the feedstock used was $1 \%$ of the total palm shell available in Malaysia, i.e., $2,587 \mathrm{~kg} \mathrm{~h}^{-1}$ bio-oil, the simulation predicted the production of $226 \mathrm{~kg} \mathrm{~h}^{-1}$ benzene, $236 \mathrm{~kg} \mathrm{~h}^{-1}$ cyclohexane and $7 \mathrm{~kg} \mathrm{~h}^{-1}$ cyclohexene, with the yield of 34,81 and $3 \%$ respectively. The preliminary economic potential was calculated to be positive. It was also observed that hydrogen was the limiting reactant in the hydrogenation reaction. Conclusion/Recommendations: The simulation study indicated positive technical and economic feasibility of hydrodeoxygenation of pyrolytic bio-oil from biomass into benzene and cyclohexane for the transportation fuel industry. This potential can be explored in more details and further findings can promote the prospect of co-processing bio-oil in standard refinery units to produce chemicals and fuels.
\end{abstract}

Key words: Bio-oil, simulation, hydrodeoxygenation, flowsheet design, biomass

\section{INTRODUCTION}

World energy consumption is predicted to grow significantly and continuously close with the global population. Contributing approximately 79\% (US Energy Information Administration, 2009) of the worldwide energy demand, fossil fuel is expected to remain the governing energy fuel as it has been for decades. However, the supply for this high demand may be retarded by the decreasing reserve of fossil oil. The dramatic fluctuations of fossil oil price furthermore raise the question of fossil oil dependability as the primary energy fuel. Despite the increasing energy needs, the utilization of fossil oil as an energy source is also becoming increasingly controversial from an environmental standpoint (US Energy Information Administration, 2009). A growing concern on the harmful environmental effects from burning fossil fuels was best portrayed via today's catastrophic greenhouse effects.

Hence, renewable energy are essential contributors to the energy portfolio as they contribute to world supply security, renovate the energy sources structure, reduce the dependency on fossil oil resources and provide opportunities to mitigate greenhouse gases. In response towards the energy crisis, an extensive study on the production of transportation fuels from an alternative renewable source i.e., bio-oil obtained via pyrolysis of biomass.

Fast pyrolysis of biomass produces bio-oil, a complex mixture of oxygenated hydrocarbons that theoretically could be a source of sustainable and environmentally friendly hydrocarbon fuels, hence making it a potential replacement for traditional diesel

Corresponding Author: Murni M. Ahmad, Department of Chemical Engineering, University Technology PETRONAS, 31750 Perak, Malaysia 
Am. J. Applied Sci., 7 (6): 746-755, 2010

Table 1: Properties of bio-oil and upgraded bio-oil (Huber et al., 2006)

\begin{tabular}{|c|c|c|c|}
\hline Aspect of comparison & High pressure liquefaction & Flash pyrolysis & Hydro deoxygenated bio-oils \\
\hline \multicolumn{4}{|l|}{ Elemental analysis } \\
\hline Carbon (wt \%) & 72.6 & 43.5 & $85.3-89.2$ \\
\hline Hydrogen (wt \%) & 8.0 & 7.3 & $10.5-14.1$ \\
\hline Oxygen (wt \%) & 16.3 & 49.2 & $0.0-0.7$ \\
\hline Sulfur (wt \%) & $<45$ & 29.0 & 0.005 \\
\hline $\mathrm{H} / \mathrm{C}$ atom ratio (dry) & 1.21 & 1.23 & $1.40-1.97$ \\
\hline Density $\left(\mathrm{g} \mathrm{mL}^{-1}\right)$ & 1.15 & 24.8 & $0.796-0.926$ \\
\hline Moisture (wt \%) & 5.1 & 24.8 & $0.001-0.008$ \\
\hline Higher heating value $\left(\mathrm{MJ} \mathrm{kg}^{-1}\right)$ & 35.7 & 22.6 & $42.3-45.3$ \\
\hline Viscosity $(\mathrm{cP})$ & $15.000\left(61^{\circ} \mathrm{C}\right)$ & $59 \quad\left(40^{\circ} \mathrm{C}\right)$ & $1.0-4.6\left(23^{\circ} \mathrm{C}\right)$ \\
\hline Aromatic/aliphatic carbon & & & $38 / 62-22 / 78$ \\
\hline Research Octane Number (RON) & Not available & Not available & 77 \\
\hline \multicolumn{4}{|l|}{ Distillation range (wt \%) } \\
\hline $\mathrm{IBP}-225^{\circ} \mathrm{C}$ & 8 & 44 & $97-36$ \\
\hline $225-350^{\circ} \mathrm{C}$ & 32 & Coked & $0-41$ \\
\hline
\end{tabular}

and gasoline fuels. Even so, properties such as low heating value, incompatibility with conventional fuels, ash content, high viscosity, incomplete volatility and chemical instability negatively affect the quality of biooil as a transportation fuel (Huber et al., 2006). Due to the physicochemical properties of bio-oil, an upgrading process can be used to convert bio-oil into a ready alternative to the petroleum fuel in the transportation industry. An example of the upgrading process is hydrodeoxygenation.

Hydrodeoxygenation (HDO) is one of the examples of the hydrotreatment process in which hydrogen is used to reduce the high oxygen content in bio-oil in the presence of suitable catalysts such as Cobalt-Molybdenum (CoMo) or Nickel-Molybdenum (NiMo) sulphides (Senol, 2007; Mahfud, 2007; Gutierrez et al., 2007). Theoretically for bio-oil, the reaction is performed in two stages, which is characterized by a low temperature treatment in the range of $200-250^{\circ} \mathrm{C}$ and then a more severe treatment at $350-450^{\circ} \mathrm{C}$. Through the reaction, water was produced as one of the major by-products (Gutierrez et al., 2007) and it is expected that the quality of the hydrodeoxygenated bio-oil, in terms of the content of high-value hydrocarbons i.e., cyclohexane and benzene, satisfies the standard of a ready transportation fuel.

Table 1 shows that the oxygen and moisture content in bio-oil are decreased via HDO, resulting in significant increase of heating value. HDO also reduces the viscosity to that required for fuel applications. Furthermore, the formation of saturated C-C bonds and water from the reaction of oxygen and hydrogen increases the stability of the oil and reduces the acidity level of the oil. On the other hand, the octane number was taken into consideration as it measures the maximum compression ratio which can be utilized in an engine without some of the fuel/air mixture self ignited
(Astron International, Inc., 2009). Currently, no significant comparison can be made directly as there is limited data on the octane number for high pressurized liquefaction and flash pyrolysis bio-oil. However, here it is assumed that these properties are enhanced via the decrement in the highly-oxygenated compounds composition and the increment in the benzene and cyclohexane compositions in the bio-oil.

Nevertheless, the scope of investigation on this upgrading route is quite extensive, making the experimental work exhaustive and expensive. Hence, a less expensive yet systematic simulation approach is proposed to investigate the preliminary feasibility of producing high-value hydrocarbons i.e., cyclohexane and benzene, from bio-oil in the search for potential alternative source for transportation fuel industry. The work is implemented in PETRONAS iCON simulation software.

\section{MATERIALS AND METHODS}

Chemical reaction analysis: The main process reaction on the model compound with respect to the upgrading process of bio-oil via HDO is described by Mahfud (2007) as:

$\mathrm{H}_{2}+-\left(\mathrm{CH}_{2} \mathrm{O}\right)-\rightarrow-\left(\mathrm{CH}_{2}\right)-+\mathrm{H}_{2} \mathrm{O}$

Here - $\left(\mathrm{CH}_{2} \mathrm{O}\right)$ - represents the bio-oil. However, Furimsky (2000) reports that most of the studies on the upgrading of bio-oil related compounds via HDO concentrate mainly on the stabilization of phenols as the major oxygen-containing products. Consequently, it may be well presented in term of HDO of phenols with respect to the HDO of the stabilized liquids. Figure 1 illustrates the reaction scheme for the HDO of phenols. 
Am. J. Applied Sci., 7 (6): 746-755, 2010

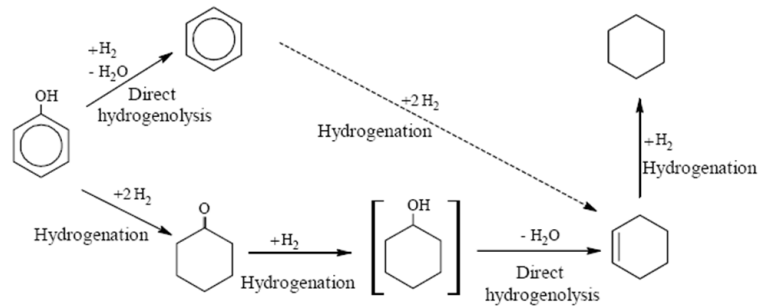

Fig. 1: Reaction scheme for the catalytic hydrotreating of phenol (Senol, 2007)

\begin{tabular}{|c|c|c|}
\hline Model compound & Reaction & \\
\hline Guaiacol $\rightarrow$ Catechol & $\begin{array}{l}\mathrm{C}_{6} \mathrm{H}_{4}(\mathrm{OH})\left(\mathrm{OCH}_{3}\right)+\mathrm{H}_{2} \rightarrow \mathrm{C}_{6} \mathrm{H}_{4} \\
(\mathrm{OH})(\mathrm{OH})+\mathrm{CH}_{4}\end{array}$ & (2) \\
\hline Catechol $\rightarrow$ Phenol & $\begin{array}{l}\mathrm{C}_{6} \mathrm{H}_{4}(\mathrm{OH})(\mathrm{OH})+\mathrm{H}_{2} \rightarrow \mathrm{C}_{6} \mathrm{H}_{5} \\
(\mathrm{OH})+\mathrm{H}_{2} \mathrm{O}\end{array}$ & (3) \\
\hline Phenols $\rightarrow$ Benzene & $\mathrm{C}_{6} \mathrm{H}_{5}(\mathrm{OH})+\mathrm{H}_{2} \rightarrow \mathrm{C}_{6} \mathrm{H}_{6}+\mathrm{H}_{2} \mathrm{O}$ & (4) \\
\hline Phenols $\rightarrow$ Cyclohexanone & $\mathrm{C}_{6} \mathrm{H}_{5}(\mathrm{OH})+\mathrm{H}_{2} \rightarrow \mathrm{C}_{6} \mathrm{H}_{10} \mathrm{O}$ & (5) \\
\hline $\begin{array}{l}\text { Cyclohexanone } \rightarrow \\
\text { Cyclohexanol }\end{array}$ & $\mathrm{C}_{6} \mathrm{H}_{10} \mathrm{O}+\mathrm{H}_{2} \rightarrow \mathrm{C}_{6} \mathrm{H}_{11}(\mathrm{OH})$ & (6) \\
\hline $\begin{array}{l}\text { Cyclohexanol } \rightarrow \\
\text { Cyclohexene }\end{array}$ & $\mathrm{C}_{6} \mathrm{H}_{11}(\mathrm{OH}) \rightarrow \mathrm{C}_{6} \mathrm{H}_{10}+\mathrm{H}_{2} \mathrm{O}$ & (7) \\
\hline $\begin{array}{l}\text { Cyclohexene } \rightarrow \\
\text { Cyclohexane }\end{array}$ & $\mathrm{C}_{6} \mathrm{H}_{10}+\mathrm{H}_{2} \rightarrow \mathrm{C}_{6} \mathrm{H}_{12}$ & (8) \\
\hline
\end{tabular}

Based on the reaction scheme in Fig. 1 and reports by Furimsky (2000) and Gutierrez et al. (2007), the overall process reactions of the model compounds can be summarized as listed in Table 2.

Process development: The conditions employed during the upgrading of bio-oil differ depending on its source of origins i.e., either through highly pressurized liquefaction or pyrolysis process. In this study, the biooil from the biomass fast pyrolysis is upgraded via HDO which consists of two stages. At the end of the second stage, the oxygen content in the bio-oil is expected to decrease significantly.

Viljava (2001) states that most of the HDO studies reported in the literature have been carried out using model compounds and mixtures of model compounds to represent bio-oil. A recent review by Furimsky (2000) that extensively summarizes the HDO experimental work, highlights that most work on the process to produce transport fuel grade from bio-oil were focused on phenols and furans due to their low reactivity in HDO. Hence, in this study, phenols and substituted phenols, which are the major oxygen compound found in bio-oil, are considered to represent the bio-oil in the simulation.

Based on the recommendations proposed by Furimsky (2000) and supported by Gutierrez et al. (2007), Guaiacol (GUA) and substituted GUAs are selected as the initial model compounds to represent bio-oil in the simulation. This is acceptable due to the

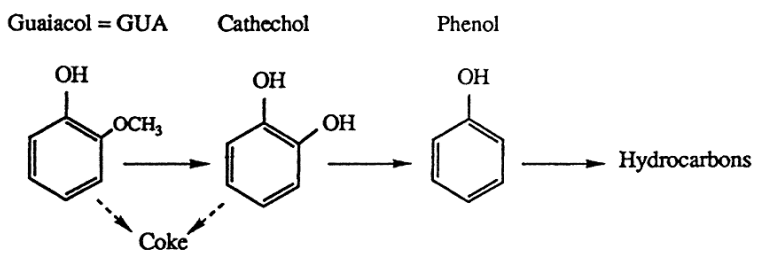

Fig. 2: Mechanism of HDO of GUA (Astron International, Inc., 2009)

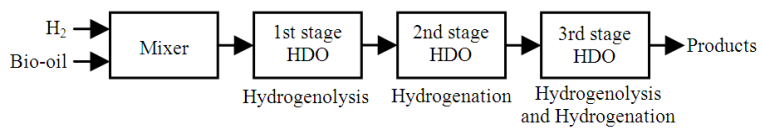

Fig. 3: Overall process flow block diagram for upgrading process of bio-oil via HDO

relatively high concentrations and low stability of these compounds in bio-oil. The study by (Astron International, Inc., 2009; Furimsky, 2000) states that most of the results on the HDO of bio-oil focus on the GUA disappearance, meanwhile phenols are accounted for most of the disappearance of GUA. Figure 2 below illustrates the mechanism of HDO of GUA.

As the reactions proceed as proposed in Table 2, the simulated conversion of the reactant along with the yield and selectivity of the products provides valuable information in determining the amount of product formed and reactant consumed throughout the reaction.

Nevertheless, Furimsky (2000) notes that for the upgrading of bio-oil from pyrolysis, an additional hydrogenation stage may be needed because of a high aromatics content of products after a two-stage upgrading. The main objective of the second upgrading stage conducted under typical hydroprocessing conditions is to have a complete HDO. Furimsky (2000) reports that the feed treatment prior to upgrading is usually neglected although it may slow down catalyst deactivation. Therefore, a three-stage process is proposed for this simulation work.

Process flow description: Figure 3 shows the overall process flow block diagram developed for the simulation to upgrade bio-oil via HDO. The feeds to this process consist of bio-oil and hydrogen. The process developed is described in more details.

\section{Process simulation using iCON:}

Assumptions: The major assumptions used in the simulation are:

- The approximate amount of the selected feedstock i.e., palm shell available in Malaysia annually is shown in Table 3: 


$$
\begin{aligned}
\text { Availability }= & \frac{938 \mathrm{~kg}}{\text { year.ha }} \times \frac{1 \text { year }}{365 \text { days }} \times 4,165,215 \text { ha } \\
& \times \frac{1 \text { ton }}{1000 \mathrm{~kg}}=\frac{10,704.03 \text { ton }}{\text { day }}
\end{aligned}
$$

- Based on the conversion of the bio-oil obtained from the pyrolysis of palm shell, the bio-oil flowrate used in the simulation is $2,586.81 \mathrm{~kg} \mathrm{~h}^{-1}$, i.e. approximately $1 \%$ of the total biomass available from palm shell in Malaysia annually. The detailed calculations are shown in Table 4:

Flowrate of liquid product

$$
\begin{aligned}
& =1 \% \times 6,208.34 \frac{\text { ton }}{\text { day }} \times \frac{1 \text { day }}{24 \mathrm{~h}} \times \frac{1000 \mathrm{~kg}}{1 \text { ton }} \\
& =2,586.81 \frac{\mathrm{kg}}{\mathrm{h}}
\end{aligned}
$$

- A mixture of $4.82 \%$ GUA, $28.30 \%$ phenol and $66.88 \%$ inert is used to represent the fraction of bio-oil (Islam et al., 1999)

- HDO of bio-oil is represented as the HDO of GUA to phenol and HDO of phenol to hydrocarbons (Gutierrez et al., 2007; Furimsky, 2000; Viljava, 2001)

- 1,2-benzenediol is selected as the hypothetical compound for catechol in the simulation (Afifi et al., 1996)

- Conversion of cyclohexene to cyclohexane is assumed to be $97 \%$ (Senol, 2007)

- Main HDO products of phenols are benzene, cyclohexane and cyclohexene (Senol, 2007)

- $\quad$ Side HDO product of GUA is methane while water is the side HDO products of 1,2-benzenediol and phenol

Table 3: Annual availability of palm shell in Malaysia

\begin{tabular}{|c|c|c|}
\hline Parameter & $\begin{array}{l}\text { Flowrate of bio-oil mixture } \\
\text { calculated using results by } \\
\text { Islam et al. (1999) and } \\
\text { Viljava (2001) }\end{array}$ & $\begin{array}{l}\text { Flowrate of bio-oil } \\
\text { mixture in this study }\end{array}$ \\
\hline Feed (ton day ${ }^{-1}$ ) & 0.012 & $10,704.03$ \\
\hline $\begin{array}{l}\text { Liquid product } \\
\text { yield (wt \%) }\end{array}$ & 58 & 58 \\
\hline $\begin{array}{l}\text { Flowrate of liquid } \\
\text { product (ton } \text { day }^{-1} \text { ) }\end{array}$ & $\begin{array}{l}=0.012 \times 0.58 \\
=0.0070\end{array}$ & $\begin{array}{l}=10,704.03 \times 0.58 \\
=6,208.34\end{array}$ \\
\hline
\end{tabular}

\begin{tabular}{lllll}
\hline $\begin{array}{l}\text { Oil palm } \\
\text { waste }\end{array}$ & $\begin{array}{l}\text { Dry amount } \\
\left(\mathrm{kg} \mathrm{year} \mathrm{ha}^{-1}\right)\end{array}$ & Areas (ha) & $\begin{array}{l}\text { Price } \\
\left(\mathrm{RM} \mathrm{ton}{ }^{-1}\right)\end{array}$ & References \\
\hline Palm & 938 & $4,165,215$ & 40 & (Islam et al., 1999; \\
shell & & & & Noor et al., 1990; \\
& & & & $\begin{array}{l}\text { United Nations } \\
\text { Development } \\
\end{array}$ \\
& & & & Programme, 2007) \\
\hline
\end{tabular}

Table 4: The calculation on flowrate of bio-oil as used in the simulation work in comparison with other work
Property package: The Soave-Redlich-Kwong property package is selected to calculate the thermodynamic data of the phases (Viljava and Krause, 1996). Besides its success in applications, the SoaveRedlich-Kwong property package is also used to allow comparison between the results obtained from this study and to those by others that have used the same property package.

Feed stream: Table 5 lists the composition of bio-oil assumed in the simulation.

The operating parameters for the feed streams are summarized in Table 6.

The bio-oil flowrate was used to calculate the minimum hydrogen flowrates to be consumed in the HDO reaction.

HDO of GUA: This stage consists of the hydrogenolysis of the methoxy group from GUA which produces a fraction of Catechol (CAT) and methane. Figure 4 illustrates the primary mechanism of the reaction.

The operating parameters for the reactor are given in Table 7.

\section{Table 5: The composition of bio-oil (Islam et al., 1999)}

\begin{tabular}{lc}
\hline Chemical compound identification & $\begin{array}{l}\text { Quantification } \\
\text { (wt \% of bio-oil) }\end{array}$ \\
\hline Guaiacol (GUA) & 4.82 \\
Phenol & 28.30 \\
Inert (hypothetical compound) & 66.88 \\
\hline
\end{tabular}

Table 6: Operating parameters for feed stream

\begin{tabular}{lllll}
\hline Stream & $\begin{array}{l}\text { Temperature } \\
\left({ }^{\circ} \mathrm{C}\right)\end{array}$ & $\begin{array}{l}\text { Pressure } \\
(\mathrm{atm})\end{array}$ & $\begin{array}{l}\text { Mass flow } \\
\text { rate }\left(\mathrm{kg} \mathrm{h}^{-1}\right)\end{array}$ & $\begin{array}{l}\text { Vapor } \\
\text { fraction }\end{array}$ \\
\hline Bio-oil & 30 & 1 & $2,000-3,000$ & - \\
Hydrogen & 30 & 1 & $0-100$ & 1.0 \\
\hline
\end{tabular}

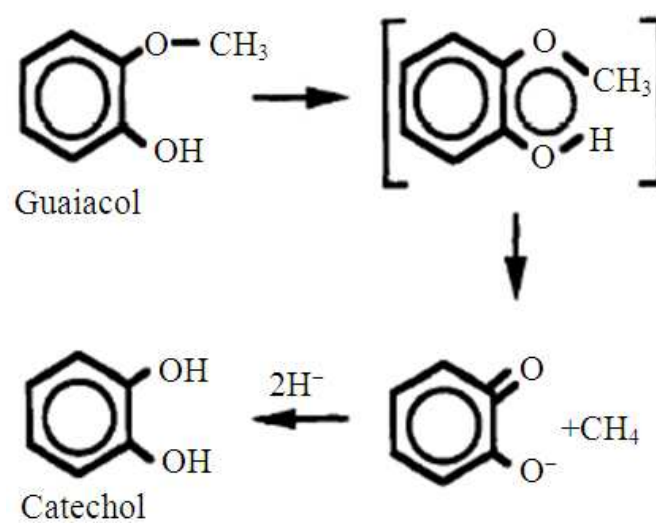

Fig. 4: Primary reaction mechanism (Afifi et al., 1996) 
Am. J. Applied Sci., 7 (6): 746-755, 2010

Table 7: Operating parameters for conversion reactor for HDO of

\begin{tabular}{lll}
\hline Parameter & & Reference \\
\hline Temperature $\left({ }^{\circ} \mathrm{C}\right)$ & 250 & (Gutierrez et al., 2009) \\
Pressure $(\mathrm{MPa})$ & $8.0-8.2$ & (Gutierrez et al., 2007; 2009) \\
Conversion $(\%)$ & 48 & (Gutierrez et al., 2009) \\
Catalyst & $\mathrm{CoMo} / \mathrm{Al}_{2} \mathrm{O}_{3}$ & (Gutierrez et al., 2007; 2009) \\
\hline
\end{tabular}

Table 8: Properties of 1,2-benzenediol and catechol

\begin{tabular}{lll}
\hline Compound & 1,2-benzenediol & Catechol \\
\hline Chemical formula & $\mathrm{C}_{6} \mathrm{H}_{6} \mathrm{O}_{2}$ & $\mathrm{C}_{6} \mathrm{H}_{6} \mathrm{O}_{2}$ \\
Molecular weight & 110.11 & 110.11 \\
Normal boiling point $\left({ }^{\circ} \mathrm{C}\right)$ & 245.50 & 245.50 \\
Liquid density @ $298 \mathrm{~K}\left(\mathrm{~kg} \mathrm{~m}^{-3}\right)$ & 1225.78 & 1275.00 \\
\hline
\end{tabular}

Table 9:Operating parameters for conversion reactor for HDO of

\begin{tabular}{lll}
\multicolumn{1}{c}{ CAT } & & \\
\hline Parameter & & Reference \\
\hline Temperature $\left({ }^{\circ} \mathrm{C}\right)$ & 400 & (Afifi et al., 1996; \\
& & Dalloro et al., 2005) \\
Pressure (bar) & 3 & (Dalloro et al., 2005) \\
Conversion $(\%)$ & 100 & (Dalloro et al., 2005) \\
Catalyst & $\mathrm{CoMo} / \mathrm{Al}_{2} \mathrm{O}_{3}$ & (Dalloro et al., 2005) \\
\hline
\end{tabular}

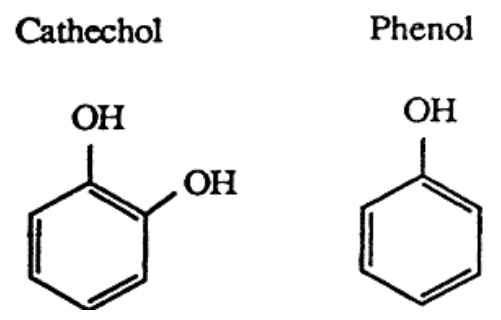

Fig. 5: Reaction scheme for the hydrotreating of CAT (Afifi et al., 1996)

CAT, the product of the GUA hydrogenolysis, is represented as 1,2-benzenediol. This is due to the complexity and error in the simulation that was encountered when assuming a hypothetical compound for CAT. To justify the assumption, the comparison between the properties of 1,2-benzenediol and CAT compounds are listed in Table 8.

Based on the comparison in Table 8 , the relative deviation in the liquid density was calculated to be $3.86 \%$ and was taken into consideration in representing 1,2-Benzenediol as CAT compound.

The next stage is the reaction that consists of the elimination of one $\mathrm{OH}$ group from CAT to produce phenols which are the predominant primary products. In this case, phenols as the major oxygen containing products underwent the stabilization stage as the main reactant. Figure 5 illustrated the reaction scheme for the hydrotreating of CAT.

The operating parameters for the second stage of HDO are given in Table 9.
Table 10: Operating parameters for conversion reactor for stabilization stage

\begin{tabular}{|c|c|c|}
\hline \multicolumn{2}{|l|}{ Parameter } & \multirow{2}{*}{$\begin{array}{l}\text { Reference } \\
\text { (Gutierrez et al., 2009) }\end{array}$} \\
\hline Temperature $\left({ }^{\circ} \mathrm{C}\right)$ & 300 & \\
\hline Pressure (MPa) & $8.0-8.2$ & (Gutierrez et al., 2007; 2009) \\
\hline Conversion (\%) & & \\
\hline Phenol $\rightarrow$ Benzene & 34 & (Gutierrez et al., 2009) \\
\hline Phenol $\rightarrow$ Cyclohexanone & 34 & (Gutierrez et al., 2009) \\
\hline Cyclohexanone $\rightarrow$ Cyclohexanol & 100 & (Senol, 2007) \\
\hline Cyclohexanol $\rightarrow$ Cyclohexene & 100 & (Senol, 2007) \\
\hline Cyclohexene $\rightarrow$ Cyclohexane & 97 & \\
\hline Catalyst & $\mathrm{CoMo} / \mathrm{Al}_{2} \mathrm{O}_{3}$ & $\begin{array}{l}\text { (Viljava, 2001; } \\
\text { Gutierrez et al., 2009) }\end{array}$ \\
\hline
\end{tabular}

Stabilization stage: The breakdown of the whole reaction involved in this stage along with the operating parameters for the reactor, are given in Table 10. Initially, benzene and cyclohexanone were formed simultaneously from the conversion of phenol. A series of reactions occur, leading to the formation of hydrocarbon products; cyclohexane and cyclohexene (Senol, 2007).

\section{RESULTS}

Process simulation: To develop the bio-oil upgrading process flowsheet, the iCON (Virtual Materials Group Inc., 2009) process simulation package is employed. This commercial process simulator that is developed by PETRONAS, Malaysia's national oil corporation, in collaboration with Virtual Materials Group (VMG) Inc., is based on Sim 42 and runs on VMGThermo as the plug-in thermodynamics property package database standard.

The simulated process flowsheet shown in Fig. 6 has been modeled as a steady-state system to produce a base case without the potentially complex consideration of dynamics. The Soave-Redlich-Kwong property package is used in the simulation so that results comparison can be made to the simulation work done by others that used the same property package.

Referring to Fig. 6, bio-oil and hydrogen, initially in the mixture phase of liquid and vapor, are heated up using a furnace to achieve a full vapor phase for better mixing effects. The vapor phase is compressed to the operating pressure of $8.6 \mathrm{MPa}$ before entering conversion reactor 1 as a liquid-vapor mixture with a vapor fraction close to 1 . The mixture is then cooled to $250^{\circ} \mathrm{C}$ before it enters the first stage of the hydrogenolysis of GUA which produces CAT as the major product and methane as the by-product in the conversion reactor.

The reaction of hydrogenolysis of GUA has been carried out in a series of two conversion reactors due to its low conversion of the reactant and to achieve higher CAT purity as the reaction's main product. 


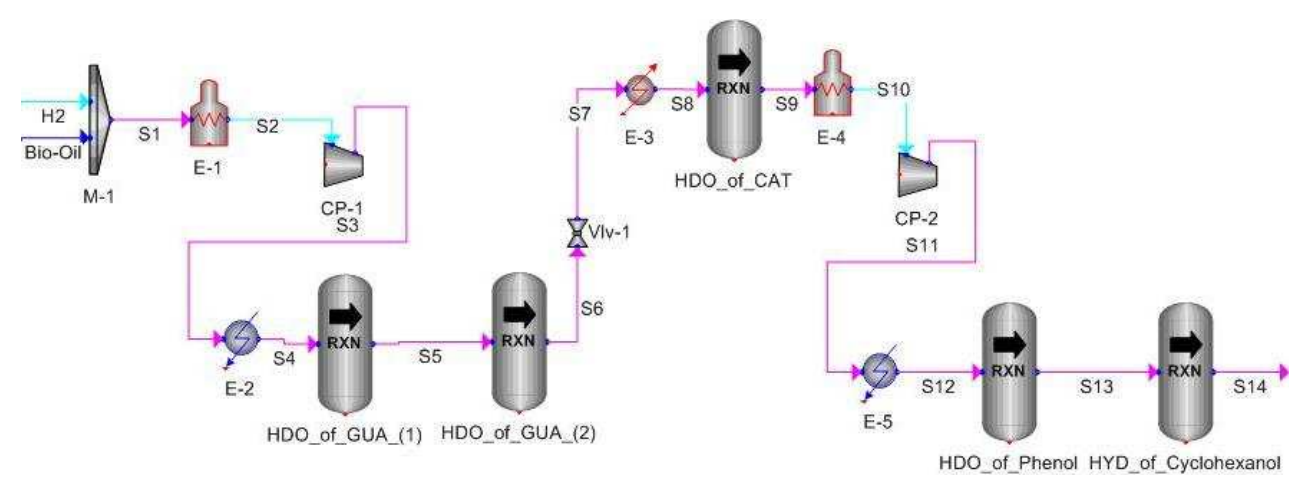

Fig. 6: iCON process simulation of the HDO of bio-oil

Table 11: Operating parameters and component mass flows for the simulation of the HDO of bio-oil

\begin{tabular}{|c|c|c|c|c|c|c|c|c|c|c|c|c|c|c|c|c|}
\hline Name & Bio-oil & $\mathrm{H} 2$ & S1 & S2 & S3 & S4 & S5 & S6 & S7 & S8 & S9 & S10 & S11 & S1 & S13 & S14 \\
\hline VapFrac & 0 & 1 & 0.3901 & 1 & 0.6029 & 0.4134 & 0.4154 & 0.4169 & 0.5829 & 0.6042 & 0.6046 & 1 & 0.603 & 0.4749 & 0.4461 & 0.4688 \\
\hline $\mathrm{T}\left({ }^{\circ} \mathrm{C}\right)$ & 30 & 30 & 30 & 1939.2 & 1316.6 & 250 & 250 & 250 & 249.8 & 400 & 400 & 2453.4 & 1573.9 & 300 & 300 & 300 \\
\hline $\mathrm{P}(\mathrm{kPa})$ & 101.33 & 101.33 & 101.33 & 50.66 & 8600 & 8400 & 8200 & 8000 & 340 & 320 & 300 & 280 & 8400 & 820 & 8000 & 7800 \\
\hline $\begin{array}{l}\text { Mass flow } \\
\text { inert* }^{*}\left(\mathrm{~kg} \mathrm{~h}^{-1}\right)\end{array}$ & 1730.06 & 0 & 1730.06 & 1730.06 & 1730.06 & 1730.06 & 1730.06 & 1730.06 & 1730.06 & 1730.06 & 1730.06 & 1730.06 & 1730.06 & 1730.0 & 1730.06 & 1730.06 \\
\hline $\begin{array}{l}\text { Mass flow guaiacol } \\
\left(\mathrm{kg} \mathrm{h}^{-1}\right)\end{array}$ & 124.68 & 0 & 124.68 & 124.68 & 124.68 & 124.68 & 64.84 & 33.71 & 33.71 & 33.71 & 33.71 & 33.71 & 33.71 & 33.71 & 33.71 & 33.71 \\
\hline $\begin{array}{l}\text { Mass flow } 1,2 \\
\text {-Benzenediol }\left(\mathrm{kg} \mathrm{h}^{-1}\right)\end{array}$ & 0 & 0 & 0 & 0 & 0 & 0 & 53.09 & 80.69 & 80.69 & 80.69 & 0 & 0 & 0 & 0 & 0 & 0 \\
\hline $\begin{array}{l}\text { Mass flow } \\
\text { Phenol }\left(\mathrm{kg} \mathrm{h}^{-1}\right)\end{array}$ & 732.07 & 0 & 732.07 & 732.07 & 732.07 & 732.07 & 732.07 & 732.07 & 732.07 & 732.07 & 801.03 & 801.03 & 801.03 & 801.03 & 256.33 & 256.33 \\
\hline $\begin{array}{l}\text { Mass flow } \\
\text { Hydrogen }\left(\mathrm{kg} \mathrm{h}^{-1}\right)\end{array}$ & 0 & 32 & 32 & 32 & 32 & 32 & 31.03 & 30.52 & 30.52 & 30.52 & 29.50 & 29.50 & 29.50 & 29.50 & 11.54 & 0.0514 \\
\hline $\begin{array}{l}\text { Mass flow } \\
\text { Methane }\left(\mathrm{kg} \mathrm{h}^{-1}\right)\end{array}$ & 0 & 0 & 0 & 0 & 0 & 0 & 7.73 & 11.76 & 11.76 & 11.76 & 11.76 & 11.76 & 11.76 & 11.76 & 11.76 & 11.76 \\
\hline $\begin{array}{l}\text { Mass flow } \\
\text { Water }\left(\mathrm{kg} \mathrm{h}^{-1}\right)\end{array}$ & 0 & 0 & 0 & 0 & 0 & 0 & 0 & 0 & 0 & 0 & 13.2 & 13.2 & 13.2 & 13.2 & 65.34 & 117.47 \\
\hline $\begin{array}{l}\text { Mass flow } \\
\text { Benzen }\left(\mathrm{kg} \mathrm{h}^{-1}\right)\end{array}$ & 0 & 0 & 0 & 0 & 0 & 0 & 0 & 0 & 0 & 0 & 0 & 0 & 0 & 0 & 226.05 & 226.05 \\
\hline $\begin{array}{l}\text { Mass flow } \\
\text { Cyclohexanone } \\
\left(\mathrm{kg} \mathrm{h}^{-1}\right)\end{array}$ & 0 & 0 & 0 & 0 & 0 & 0 & 0 & 0 & 0 & 0 & 0 & 0 & 0 & 0 & 284.02 & 0 \\
\hline $\begin{array}{l}\text { Mass flow } \\
\text { Cyclohexanol } \\
\left(\mathrm{kg} \mathrm{h}^{-1}\right)\end{array}$ & 0 & 0 & 0 & 0 & 0 & 0 & 0 & 0 & 0 & 0 & 0 & 0 & 0 & 0 & 0 & 0 \\
\hline $\begin{array}{l}\text { Mass flow } \\
\text { Cyclohexane } \\
\left(\mathrm{kg} \mathrm{h}^{-1}\right)\end{array}$ & 0 & 0 & 0 & 0 & 0 & 0 & 0 & 0 & 0 & 0 & 0 & 0 & 0 & 0 & 0 & 7.13 \\
\hline $\begin{array}{l}\text { Mass flow } \\
\text { Cyclohexane } \\
\left(\mathrm{kg} \mathrm{h}^{-1}\right)\end{array}$ & 0 & 0 & 0 & 0 & 0 & 0 & 0 & 0 & 0 & 0 & 0 & 0 & 0 & 0 & 0 & 236.25 \\
\hline
\end{tabular}

The operating pressure of the product stream from reactor 2 is reduced using a valve to $3.4 \mathrm{MPa}$ before the stream is heated to $400^{\circ} \mathrm{C}$ prior to its entrance into the third conversion reactor. In this reactor, CAT as the main reactant, is hydrotreated with hydrogen to produce phenol as the reaction's major product and water as the by-product.

The product mixture from this reactor is once again heated up to achieve a vapor fraction of 1 , compressed to $8.4 \mathrm{MPa}$ and cooled to $300^{\circ} \mathrm{C}$ before it undergoes the next stage of the reaction. HDO of phenol, which produces hydrocarbons as the major product and water as the by-product, occurs here in the conversion reactor.

During this reaction, phenol is hydrotreated with hydrogen and converted into benzene through hydrogenolysis and into cyclohexanone through hydrogenation, simultaneously. Cyclohexanone is further hydrogenated completely to produce cyclohexanol where these two compounds are the reaction intermediates for the formation of hydrocarbons. Complete hydrogenolysis of cyclohexanol produces cyclohexene as one of the hydrocarbon products and cyclohexane was formed through the hydrogenation of cyclohexene.

The operating parameters for the whole flowsheet are tabulated in Table 9. The mass balance for the flowsheet at the given operating conditions is given in Table 11. Based on the simulation performed as illustrated in Fig. 6, approximately $226.05 \mathrm{~kg} \mathrm{~h}^{-1}$ of benzene, $236.25 \mathrm{~kg} \mathrm{~h}^{-1}$ cyclohexane and $7.13 \mathrm{~kg} \mathrm{~h}^{-1}$ of 
cyclohexene are produced from $2,586.81 \mathrm{~kg} \mathrm{~h}^{-1}$ of bio-oil.

Economic potential: Benzene and cyclohexane are valuable materials especially in the transportation and petrochemical industries. For one, benzene and cyclohexane can be sold as a solvent for the production of ethanol fuel. Benzene is used to produce intermediates such as ethylbenzene for styrene production and cumene for phenol and acetone, while cyclohexane is consumed to produce nylon (ICIS.com, 2008a; 2008b). Table 12 shows the cost for raw materials and selling prices for products of HDO of biooil.

The preliminary Economic Potential i.e., level 1 (EP1) for HDO of bio-oil process hourly is:

EP $1=$ Revenue-Cost of raw materials

$\mathrm{EP} 1=$ Benzene produced + Cyclohexane produced Bio-oil consumed - Hydrogen consumed

$\approx$ MYR 1934

(Note: Currency exchange USD $1.00=$ MYR

3.70 as of 21 February 2009)

$\approx$ USD 523

The calculated EP1 value indicates positive potential for the process.

Results comparison: Table 13 shows the product yield and selectivity calculated based on the results obtained from the simulation using iCON using Eq. 1-3:

Conversion $=\frac{\text { moles of reactant converted in reactor }}{\text { moles of reactant fed to reactor }} \times 100$

Selectivity $=\frac{\text { moles of desired product formed }}{\text { moles of reactant converted in reactor }} \times 100(2)$

Yield $=\frac{\text { moles of desired product formed }}{\text { moles of reactant fed to reactor }} \times 100$

Table 12: Cost of bio-oil and hydrogen and selling prices of benzene and cyclohexane

\begin{tabular}{lll}
\hline Material & Cost $\left(\mathrm{RM} \mathrm{ton}^{-1}\right)$ & $\begin{array}{l}\text { Selling price }\left(\mathrm{RM} \mathrm{ton}{ }^{-1}\right) \\
\text { (ICIS.com, 2008a; 2008b) }\end{array}$ \\
\hline Bio-oil & 40.00 & \\
Hydrogen & 4217.00 & \\
Benzene & & $4,275.00$ \\
Cyclohexane & & $5,106.25$ \\
\hline
\end{tabular}

Table 13: Product yield and selectivity

\begin{tabular}{llll}
\hline Product & $\begin{array}{l}\text { Total mole } \\
\text { of product }\end{array}$ & Selectivity (\%) & Yield (\%) \\
\hline Benzene & 2.89 & 50.00 & 34.00 \\
Cyclohexane & 2.81 & 83.28 & 81.19 \\
Cyclohexene & 0.09 & 3.06 & 3.06 \\
\hline
\end{tabular}

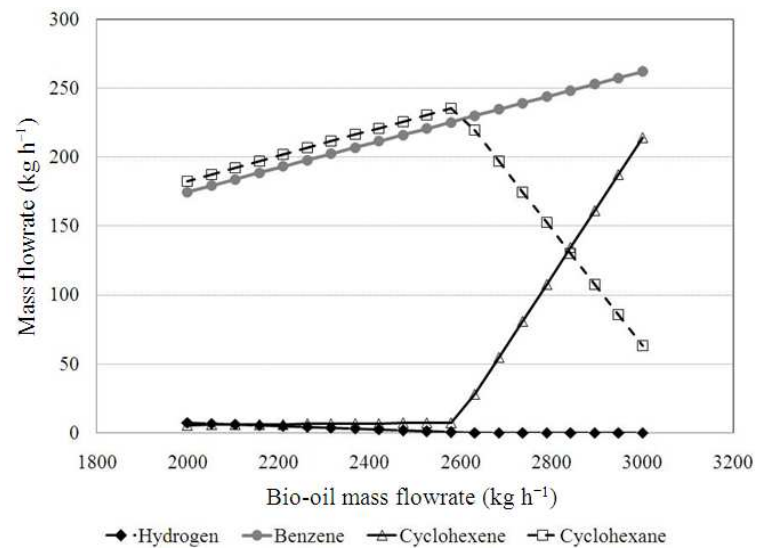

Fig. 7: The effect of bio-oil flowrate on the products distribution

From Table 13, the selectivity for benzene is approximately $50 \%$. This phenomenon can be explained by the fact that HDO of phenol simultaneously produces benzene and cyclohexanone as its major products. The selectivity for cyclohexane is higher compared to selectivity for cyclohexene. This explains why the major products for the HDO of phenol (Senol, 2007) are benzene and cyclohexane, while the yield for cyclohexene never exceeds $2 \%$.

The relative deviation between the cyclohexene yields predicted in this study and published by Senol (2007) is $53 \%$.

Profiles for the products distribution: Figure 7 illustrates the relationship between the bio-oil flowrate and the products distribution which comprises of the mass flowrate of hydrogen consumed and of other products for HDO of phenol i.e. benzene, cyclohexane and cyclohexene. From the graph, it is clearly observed that as the flowrate of bio-oil is increased from 2000$3000 \mathrm{~kg} \mathrm{~h}^{-1}$, the formation of benzene increases. Meanwhile, cyclohexene amount increases slowly at first then drastically after a certain increment in the biooil flowrate. The amount of cyclohexane increases with the increasing amount of bio-oil and beyond a certain point, it drops dramatically.

Figure 8 and 9 display the relationship between the hydrogen flowrate with the final distribution of benzene, cyclohexane and cyclohexene. It is noted that the production of cyclohexane i.e., one of the major products for HDO of phenol is directly increasing with respect to the hydrogen supply for this reaction. The amount of cyclohexene, the intermediate product that is converted into cyclohexane, is expectedly decreasing with the increase in the hydrogen supply. 
Am. J. Applied Sci., 7 (6): 746-755, 2010

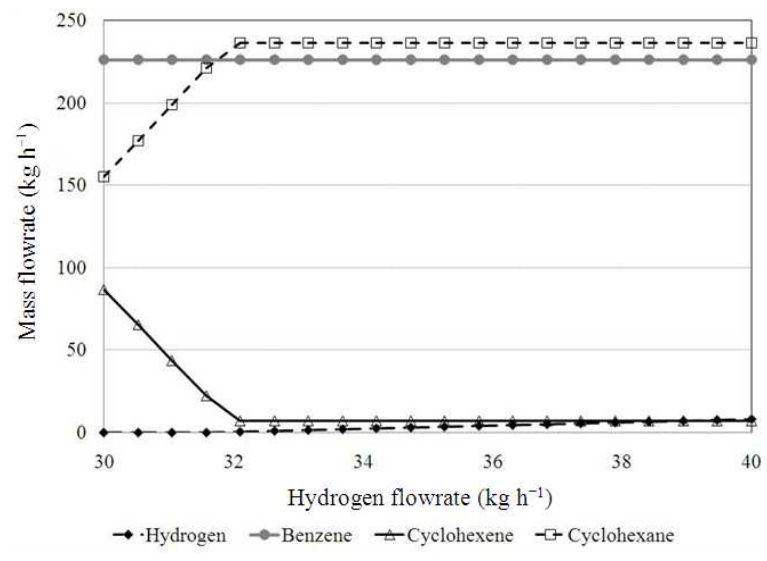

Fig. 8: The effect of hydrogen flowrate on the product distribution

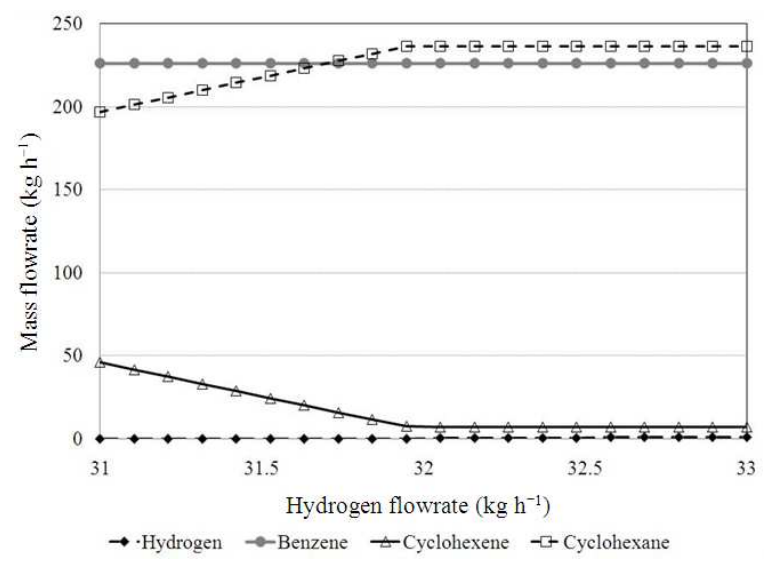

Fig. 9: The effect of hydrogen flowrate on the product distribution

Figure 8 plots the trend for the hydrogen flowrate varying from $31-40 \mathrm{~kg} \mathrm{~h}^{-1}$ where beyond this range, there is no dramatic change observed. Figure 9 on the other hand, zooms into the region in which drastic change is observed, i.e., from $31-33 \mathrm{~kg} \mathrm{~h}^{-1}$.

\section{DISCUSSION}

Process simulation: The simulation of the upgrading process was performed at the operating conditions within a selected range based on empirical data from referred literatures. The simulation indicates the feasibility of producing benzene and cyclohexane through a series of reactions that eliminate the oxygen compound present in bio-oil. Overall, the simulation converged to predict the production of the expected products as by other work.
Economic potential: The positive preliminary economic potential indeed indicates the economic viability and promising return, especially as this calculation is based on only $1 \%$ of the total available palm shell in Malaysia. Furthermore, in the midst of the recent instability of global fossil oil price, the demand for benzene and cyclohexane is expected to rise significantly in the South East Asia region especially for the transportation and petrochemical industries which produces goods to meet the population's needs.

Results comparison: The comparison study on yield and selectivity of the process shows that our results match to some extent with empirical results from literatures. This comparison study cannot be more extensive as the available literature is comparable only in terms of the reaction kinetics, element balance, reaction time and compounds concentration. Furthermore, there is a limited similarity between the thermodynamic properties for HDO of phenol used in the simulation compared to those in the experimental work.

Profiles for the products distribution: The trends observed for cyclohexene and cyclohexane amounts with respect to bio-oil flowrate increment indicates that more hydrogen is required for the hydrogenation of the increasing amount of cyclohexene to produce cyclohexane and the hydrogen feed is not enough to compensate this.

Figure 8 and 9 further indicate that hydrogen appears as the limiting reactant in producing the product of interest and it is important to determine the minimum hydrogen demand for the reaction. Based on Fig. 7-9, the optimal flowrates of bio-oil and hydrogen for the process are determined to be at 2,587 and $32 \mathrm{~kg} \mathrm{~h}^{-1}$ where maximum yields of benzene and cyclohexane are obtained. In addition, it is observed that hydrogen supply is the limiting agent in producing cyclohexane rather than cyclohexene.

Model limitations: Detailed analysis and comparison of the designated results could not be performed as there was no available inclusive literature on simulation work of similar compounds. The preliminary process flowsheet was designed based on the process synthesized and developed, resulting in the association of high degree of uncertainties based on the respective process schemes, reactions and operating parameters.

The selection of feed phases and operating parameters along with the designated unit of operation may as well contribute towards the complexity of the simulation. One example is the application of mixer to 
mix liquid bio-oil and gaseous hydrogen before they are fed to the first reactor for the production of 1,2benzenediol. There is also an issue on the necessity to heat up the bio-oil to a gaseous phase to react with hydrogen gas. Nevertheless, feasible and promising solutions may perhaps be recommended to tackle the flawed nature of the mixer by injecting hydrogen bubbles into the bio-oil feed or using a multi-zone reactor to promote the reaction contact between bio-oil and hydrogen.

Due to the limited availability of the kinetic parameters data for HDO of bio-oil, attempts to predict the reaction profiles based on the changes in the operating conditions cannot be performed in this study despite the previous reports on significant effect of temperature and pressure on product mass flow, especially with catalyst (s) utilization.

\section{CONCLUSION}

In summary, there are several challenges in upgrading bio-oil via HDO especially o the significant aspect of choosing an appropriate model compound to represent the fraction of bio-oil. However, in this study, the simulation process of upgrading bio-oil via HDO into value added chemicals is successfully performed using iCON. The simulation indicates the feasibility of producing hydrocarbons through a series of reaction by eliminating the oxygen compound present in bio-oil. This simulation work provides a platform for further investigation and process optimization that allows and promotes the concept of co-fed and co-processing in existing refineries as the results indicate the success of simulating hydrocarbons production with conventional catalysts. However, this study only includes an investigation that is focused on studying the effect of feed flowrates towards the product distribution. Hence, additional validation and extended work are essential in contributing towards the reliability of this study for further development. Nevertheless, the preliminary economic potential calculated for this study indicates good economic viability.

\section{ACKNOWLEDGEMENT}

The authors wish to thank University Technology for the facilities for the work.

\section{REFERENCES}

Afifi, A.I., E. Chornet, R.W. Thring and R.P. Overdent, 1996. The aryl ether bond reactions with H-Donor solvents: Guaiacol and tetralin in the presence of catalyst. Fuel, 75: 509-516. DOI: 10.1016/00162361(95)00199-9
Astron International, Inc., 2009. FCC Octane MON versus RON.

http://www.refiningonline.com/engelhardkb/crep/tc r4_29.htm

Dalloro, L., A. Cesana, R. Buzzoni and F. Rivetti, 2005. Process for the preparation of phenol by means of the hydrodeoxygenation of benzene-diols. United States Patent No. US 6,936,738 B2, 2005.

Furimsky, E., 2000. Catalytic hydrodeoxygenation. Applied Catal. A: Gen., 199: 147-190. DOI: 10.1016/S0926-860X(99)00555-4

Gutierrez, A., M.E. Domine and Y. Solantausta, 2007. Co-processing of upgraded bio-liquids in standard refinery units-fundamentals. Proceeding of the 15th European Biomass Conference and Exhibition, May 7-11, Berlin, pp: 1-15. http://www.biocoup.com/fileadmin/user/pdf/results /06_BIOCOUP_May07.pdf

Gutierrez, A., R.K. Kaila, M.L. Honkela, R. Slioor and A.O.I. Krause, 2009. Hydrodeoxygenation of guaiacol on noble metal catalysts. Catal. Today, 147: 239-246. DOI: 10.1016/j.cattod.2008.10.037

Huber, G.W., S. Iborra and A. Corma, 2006. Synthesis of transportation fuels from biomass: Chemistry catalysts and engineering. Chem. Rev., 106: 4044-4098. DOI: $10.1021 / \mathrm{cr} 068360 \mathrm{~d}$

ICIS.com, 2008a. Benzene uses and market data. http://www.icis.com/v2/chemicals/9075159/benzen e/uses.html

ICIS.com, 2008b. Cyclohexane (CX) uses and market data.

http://www.icis.com/v2/chemicals/9075207/cycloh exane/uses.html

Islam, F.N., R. Zailani and F.N. Ani, 1999. Pyrolytic oil from fluidised bed pyrolysis of oil palm shell and its characterization. Renew. Energy, 17: 73-84.

Mahfud, F.H., 2007. Exploratory studies on fast pyrolysis oil upgrading. Doctoral Thesis, University of Gronigen, The Netherlands.

Noor, M.J.M.M, A. Jusoh and A.H. Ghazali, 1990. Management and utilization of oil palm wastes, a review. University Pertanian Malaysia, ISBN: 9679952-61-4.

Senol, O.I., 2007. Hydrodeoxygenation of aliphatic and aromatic oxygenates on sulphided catalysts for production of 2nd generation biofuels. Doctoral Thesis, Helsinki University of Technology, Finland.

United Nations Development Programme (UNDP), 2007. Malaysia Generating Renewable Energy from Palm Oil Wastes. Facility of Global Environment, UNDP, Malaysia, ISBN: 983-390401-3. 
US Energy Information Administration, 2009. EIAAnnual Energy Outlook 2009. Early release overview. http://www.eia.doe.gov/oiaf/ieo/

Virtual Materials Group Inc., 2009. VMGSIM. http://www.virtualmaterials.com/node/6

Viljava, T.R. and A.O.I. Krause, 1996. Hydrogenolysis reactions in a batch reactor-effect of mass balance inaccuracies on the kinetic parameters. Applied Catal. A: Gen., 135: 317-328. DOI: 10.1016/0926860X(95)00262-6
Viljava, T.R., 2001. From biomass to fuels: hydrotreating of oxygen-containing feeds on a $\mathrm{CoMo} / \mathrm{Al}_{2} \mathrm{O}_{3}$ hydrodesulfurization catalyst. Doctoral Thesis, Helsinki University of Technology, Finland. 